\title{
TRANSFORMING HYDROGRAPHS IN THE HILLSLOPE SUBSURFACE
}

\author{
MARTIN ŠANDA, MILENA CÍSLEROVÁ
}

Czech Technical University in Prague, Faculty of Civil Engineering, Thákurova 7, 16629 Prague 6, Czech Republic; Mailto: martin.sanda@fsv.cvut.cz

To reveal and evaluate the mechanism of transforming rainfall into runoff in the region, where the subsurface flow plays a dominant role in the runoff formation, a continuous hydrological and climatic data monitoring has been set-up in the experimental catchment Uhlírská (the Jizera Mountains, CR). The soil profile (Dystric Cambisol), formed on the weathered granite bedrock, is shallow and highly heterogeneous. Beside a standard catchment data observation a hillslope transect was instrumented to control the flow dynamics in the soil profile. From three soil horizons, the subsurface outflow is recorded in the subsurface trench. Adjacent to the trench the soil water suction is scanned by triplets of automatic tensiometers. Within the soil profile the unsaturated regime prevails, nevertheless the soil keeps almost saturated. Nearly simultaneous reaction of suction on a rainfall in all soil horizons implies a rapid vertical flow. Local preferential flow paths are conducting infiltrating water at significantly variable rates when saturation is reached. Groundwater table, soil moisture and subsurface runoff measured at the hillslope transect and the total outflow from the catchment, are correlated. The outflow from the catchment is dominantly controlled by soil moisture however the mechanism of its generation is not yet fully understood.

KEY WORDS: Experimental Catchment, Hydrological Monitoring, Subsurface Trench, Preferential Flow, Soil Moisture, Dystric Cambisol, Crystalline Granite Bedrock.

Martin Šanda, Milena Císlerová: TRANSFORMACE HYDROGRAMU PODPOVRCHOVÉHO ODTOKU NA SVAHU. Vodohosp. Čas., 57, 2009, 4; 7 lit., 10 obr., 5 tab.

V oblasti s dominantním podpovrchovým odtokem bylo započato s kontinuálním hydrologickým a klimatickým monitoringem s cílem popsat a vyhodnotit transformaci srážky na odtok. Experimentální povodí Uhliřrská se nachází v severní části České republiky v Jizerských horách. Půdní profil, klasifikovaný jako dystrická kambizem na zvětralém žulovém podloží, je mělký a velmi heterogenní. Svahový transekt byl vystrojen pro sledování dynamiky podpovrchového odtoku. Ve třech půdních horizontech je monitorován odtok a půdní sací tlak. V půdním profilu převládá nenasycený stav, ačkoliv je půdní vlhkost dlouhodobě blízko nasycení. Rychlé vertikální proudění je indikováno téměř současnou odezvou půdního sacího tlaku na srážku ve všech půdních horizontech. Po dosažení nasycení infiltrující voda protéká preferenčními cestami s výrazně odlišnými lokálními rychlostmi. Závislost hladiny podzemní vody, půdní vlhkosti, podpovrchového odtoku ve svahovém transektu na odtoku z povodí je významná. Odtok vody z povodí, které leží na zvětralém žulovém podloží, je dominantně určován půdní vlhkostí. Přes tato zjištění není mechanismus tvorby odtoku zatím jednoznačně popsatelný.

KLÍČOVÁ SLOVA: experimentální povodí, hydrologické monitorování, podpovrchový příkop, preferenční proudění, půdní vlhkost, dystrická kambizem, krystalické žulové podloží

\section{Introduction}

Experimental catchment Uhliřrská (Fig. 1) of Černá Nisa River being a small, hilly catchment represents a source area environment typical for the headwater regions of the Czech basin. Here the structured porous soil profile plays a key role in the formation of the outflow hydrograph. Despite of the fact that the catchment outflow reacts on the rain- fall instantly, the surface runoff on the hillslopes does not occur. The catchment runoff initiates on the hillslope in the form of the subsurface flow. The process of the runoff generation, namely the mechanism of the subsurface flow generation is not completely understood.

Kirchner (2003) proposes, that there are several pools (or a continuum of stores) of water within a catchment which are mobilized under different con- 


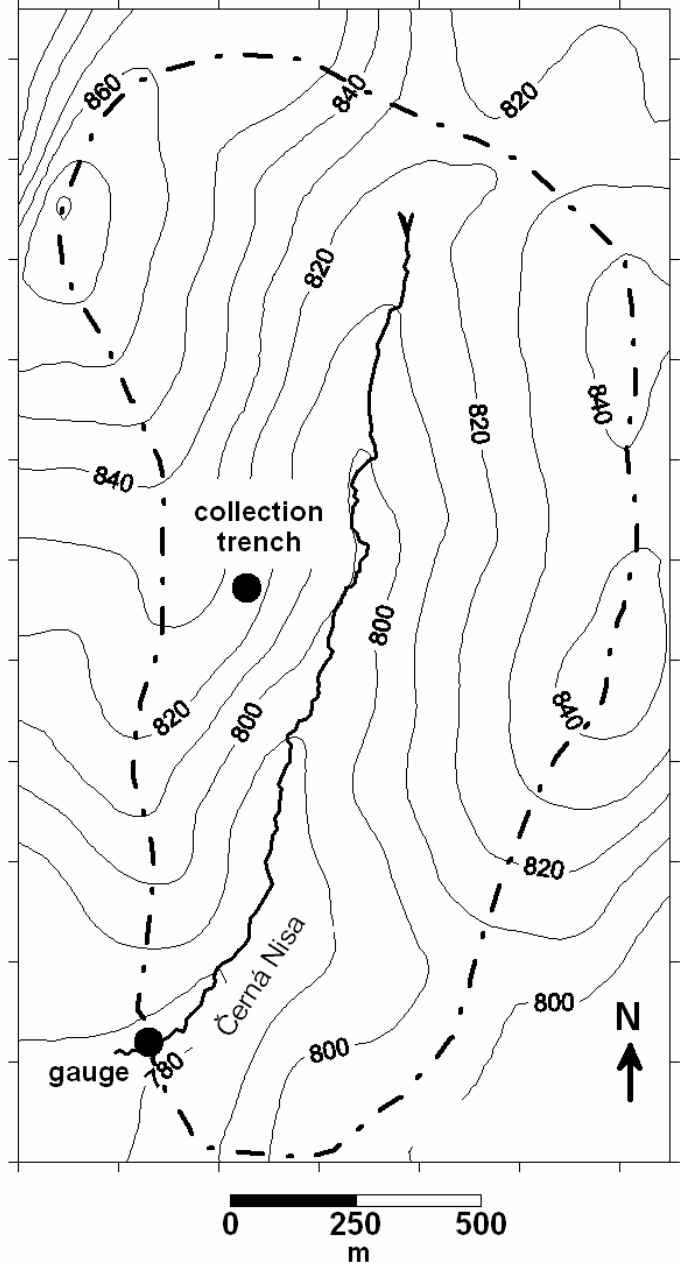

Fig. 1. Topographic map of Uhlírská catchment (elevation in [m] above sea level).

Obr. 1. Topografická mapa povodí Uhliřská (nadmořské výšky $\mathrm{v}[\mathrm{m}]$ nad mořem).

ditions. These pools can be represented e.g. by large scale structures, such as aquifers or shallow hillslope covers with a variably saturated soil profile. The outflow formation in a local scale (a plot and/or hillslope) is usually considered to be the result of subsurface discharge due to e.g. the bedrock geometry and present hydrological conditions (Bača, Bačová Mitková, 2007). However, these processes are affected primarily by the elementary flow processes occurring already at a very small scale corresponding to the local pore structure and dominated by hydraulic properties of the soil layers. Due to the heterogeneity of the soil environment, the combination of the matrix and preferential flow has to be expected (Sněhota et al., 2007).

This development in the elementary versus larger scales needs to be elucidated in detail.

At the Uhliŕská catchment experimental site a detailed research of elementary flow processes within the hillslope has been carried out since 1998 . Recently, data monitoring for hydrological and climatic processes has been on a continuous basis and extended with the focus on the continuously monitored processes in the soil profile. These measurements comprise of rainfall distribution over time, soil pore water potential fluctuation, subsurface flow appearance, with the support of standard observations as air temperature, relative air humidity, wind speed and solar radiation. Complex of these observations helps to set initial conditions for the occurrence of subsurface outflow events and monitor its development over time. A primary analysis of a series of rainfall-runoff episodes has shown that the preferential flow triggering mechanism is linked to measurable quantitative hydrological thresholds such as rainfall amount, soil suction and soil moisture. Therefore a complementary instrumentation has been intermediately added aiming on processes which influence substantially the flow dynamics (evapotranspiration) or could help to elucidate it. The data acquired up to now represent a robust collection undergoing a detailed analysis. This contribution contains a needed introductory description of the experimental catchment and the primary data analyses. The further analyses are in progress to appear soon.

\section{Materials and methods}

\section{Location of the study}

Experimental catchment Uhlířská is located in northern part of the Jizera Mountains western region, Czech Republic. The catchment valley is formed by Černá Nisa stream. The area of the catchment is $1.87 \mathrm{~km}^{2}$, with and average altitude of $822 \mathrm{~m}$ above the mean sea level (msl). The length of the valley is $2.1 \mathrm{~km}$, the average width is 0.89 $\mathrm{km}$, the average slope is $2.3 \%$ and the average length of the hillslopes is $450 \mathrm{~m}$.

The catchment is situated in a humid region with the annual precipitation exceeding $1300 \mathrm{~mm}$. In the area of interest, the sloping soil profile is shallow and highly heterogeneous. The upper hillslopes typically consist of $80 \mathrm{~cm}$ of Dystric Cambisol formed on the decayed fractured granite bedrock. The topsoil $(15 \mathrm{~cm})$ is of a peaty character. The profile below the organic layer comprises $10 \mathrm{~cm}$ of a grey-black clayey loam, $25 \mathrm{~cm}$ of a brown sandy loam and $30 \mathrm{~cm}$ of a light brown loam with a high content of the bedrock particles. The bottom of the valley is formed by a layer of peat topsoil (Histo- 
sol) (varying from 0 to $300 \mathrm{~cm}$ in its thickness) which lies on silty gelifluction gley material. Cambisols cover approximately $90 \%$ of the total catchment area while the $10 \%$ of the area is formed by Histosols of the soil profile deeper than $1 \mathrm{~m}$, found mostly in the bottom of the valley (Tachecí, Šanda, 2000).

The catchment has been deforested by up to $50 \%$ during the period 1983-1985. Deforested areas are covered by the bush grass vegetation (Calamagrostis villosa) and underwent massive reforestation of the spruce monoculture, with the isolated planting of beech, larch and rowan trees.

\section{Instrumentation to study the flow processes in the hillslope vadose zone}

To study the flow processes in a shallow soil profile which dominate catchment runoff formation, a typical hillslope transect, defined as a vertical plane of the soil profile running perpendicular to the surface contour lines has been outlined at the site Tomšovka, near the local Uhlířská catchment divide (Fig. 1). Subsurface collectors were built up (Fig. 2). Automatic data collection devices installed in and above the trench have been collecting a short-term inflow-outflow data series of hydrological events during the vegetation season, typically since May until September (Šanda et al., 2005).

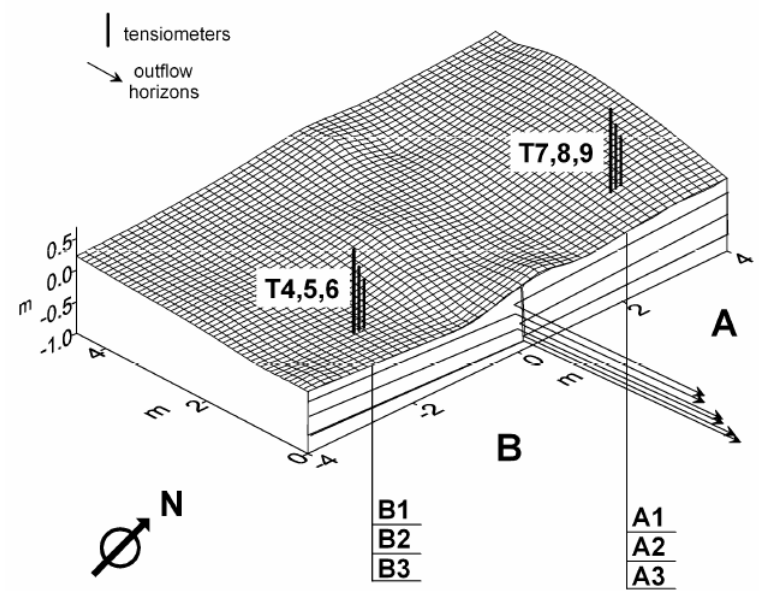

Fig. 2. Collection trench for subsurface flow with soil suction measurement.

Obr. 2. Sběrný příkop pro podpovrchový odtok s měřením půdního sacího tlaku.

In the trench, the instrumented sections correspond to the soil layer interfaces (Tab. 1): Ah horizon $(0-30 \mathrm{~cm}), \mathrm{B}$ horizon $(30-50 \mathrm{~cm})$ and $\mathrm{B}-\mathrm{C}$ horizon $(60-70 \mathrm{~cm})$. The subsurface flow is col- lected from each one of three soil horizons separately at two 4 meter long collecting sections (A and B). These are made of stainless steel sheets driven to the wall of the trench horizontally $30 \mathrm{~cm}$ in upslope direction for two upper horizons and of a concrete bed at the bottom of the trench for the deepest horizon collector (Fig. 2). Due to the depth variation in between section $\mathrm{A}$ and $\mathrm{B}$, which is caused by non-uniformity of the soil surface and of the rocky soil bed, it was impossible to insert the equipment at the desired depth. The walls of the collecting trench has been reinforced by a wooden construction and remained open until the 2000 vegetation season to check its functioning. Later the part of the trench where the water from particular depths is collected has been filled by agglomerated water resistant ash beads Liapor ${ }^{\mathrm{TM}}$ of a uniform fraction $4-8 \mathrm{~mm}$. Remaining part of the trench which contained the outflow tubing, was filled by Liapor $^{\mathrm{TM}}$ beads only at the bottom, to serve as a filter surrounding the additional drainage tube to catch up the excess water. The rest of the trench was backfilled with local soil, separated from the sampling part by wooden tar penetrated sheets wrapped into the heavy duty plastic foil. To observe the shallow subsurface flow without the effects of the flow diversion to deeper horizons due to the hydraulic nature of the trench, a single $25 \mathrm{~cm}$ deep and 4 meter long trough $\mathrm{C}$ has been built adjacent to the B section, ie. south of it, facing west side with the flow collector, same as designed for sections $\mathrm{A} 1$ and B1. Here the flow is collected from a heavy duty plastic foil driven horizontally $20 \mathrm{~cm}$ upslope. The shallow trough has been run open during vegetation seasons of 1999 and 2000 and filled with Liapor beads for the following vegetation seasons.

T a b l e 1. Depth of collectors below the surface $[\mathrm{cm}]$. $\mathrm{T}$ a b u $1 \mathrm{k}$ a 1 . Hloubka sběrných úrovní pod povrchem $[\mathrm{cm}]$.

\begin{tabular}{rrrrrrr}
\hline A1 & A2 & A3 & B1 & B2 & B3 & C1 \\
\hline 12 & 42 & 57 & 30 & 60 & 75 & 25 \\
\hline
\end{tabular}

The flow from all of the trench sections (A, B and $C$ ) has been gravitationally channelled in tubes into 7 tipping-bucket flowmeters. Pulses are recorded on Campbell CR10X-1M and Technolog Newlog3 data loggers.

The suction within the soil profile is measured by a set of 15 soil tensiometers, nested in five triplets located uphill of the trenches. Three of the triplets are installed $1 \mathrm{~m}$ above the trench in the centre of 
each of the sections $\mathrm{A}, \mathrm{B}$ and $\mathrm{C}$. The remaining two triplets were installed in the central axis above the trench sections $\mathrm{A}$ and $\mathrm{B}$, at about 10 and 20 meters further upslope. Depth of installation of the triplets in the vicinity of A and B trench sections is given in the Tab. 2.

T a b l e 2. Depth of tensiometers below the surface [cm]. $\mathrm{T} \mathrm{a} \mathrm{b} \mathrm{u} 1 \mathrm{k} \mathrm{a} 2$. Hloubka tenzometrů pod povrchem [cm].

\begin{tabular}{cccccc}
\hline T4 & T5 & T6 & T7 & T8 & T9 \\
\hline 20 & 40 & 51 & 24 & 38 & 74 \\
\hline
\end{tabular}

In each location, one of three tensiometers is always installed into one particular soil layer $(20,40$ and $60 \mathrm{~cm}$ below the soil surface). All tensiometers were fitted with the pressure transducers Honeywell 236PC15GW for the soil tension recordings. Data have been recorded continuously at 10 minute pace using the CR10X-1M data logger.

\section{Complementary measurements}

As a control link to the processes occurring at the scale of the whole hillslope, additional measurements were performed over the vegetation seasons. The ground water table has been monitored biweekly from a set of 20 shallow piezometers, the soil moisture content was scanned in 14 locations by means of the neutron probe and a set of 60 manual tensiometers was used for additional measurements of soil suction on the hillslope between the catchment divide and the stream at the bottom of the valley (Šanda, 1999).

In addition, a set of 10 shallow boreholes, located at the hillslope transect was done to stratify the upper soil and rock layer formations. Geophysical measurements by means of vertical electrical sounding were performed to estimate the depth of the unweathered bedrock at the study location (Fig. 3). Complementary dipole electromagnetic profiling was applied to identify the bedrock surface geometry and the geological fracture system of the flow region (Fig. 4). On the experimental hillslope, 85 ponded infiltration tests were performed to estimate the infiltration capacity of the topsoil. Laboratory measurements of the set of 121 retention curves and the set of 37 measurements of saturated hydraulic conductivity on $1000 \mathrm{~cm}^{3}$ undisturbed soil samples, collected at the vicinity of the trench, were performed (Šanda, 1999).

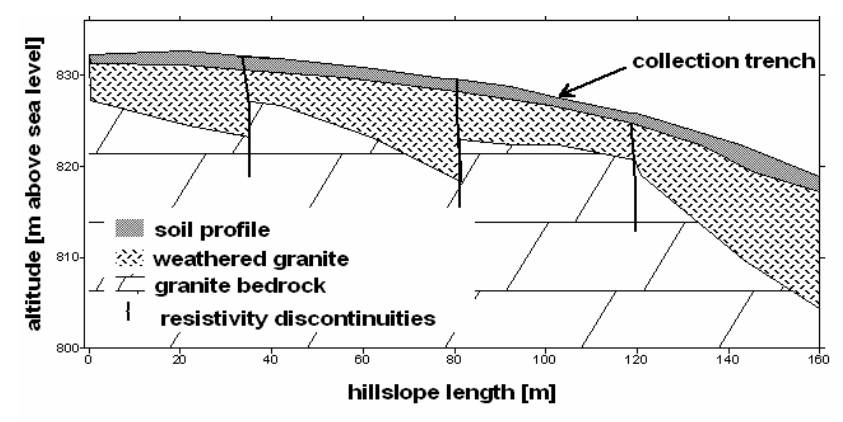

Fig. 3. Specification of the geological formation by vertical electrical survey.

Obr. 3. Specifikace geologické stavby pomocí vertikálního elektrického sondování.

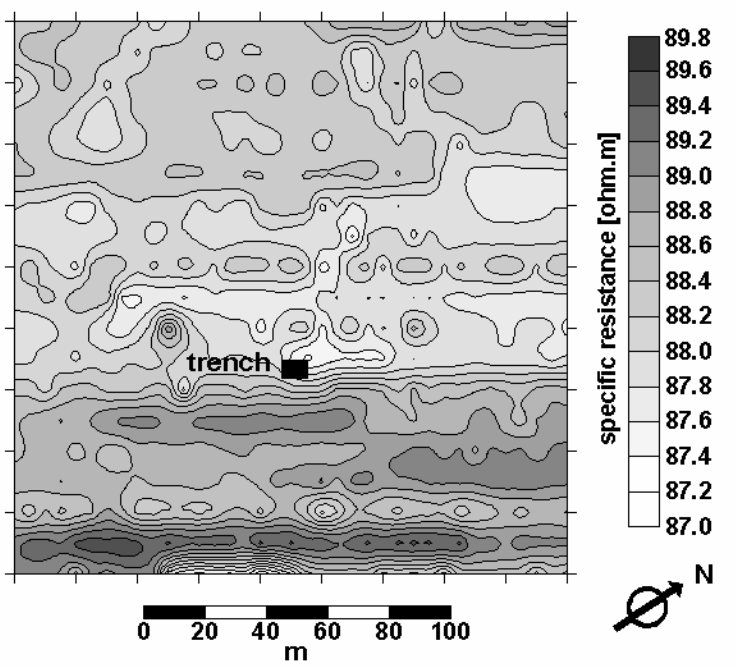

Fig. 4. Dipole electromagnetic profiling in the trench vicinity. Obr. 4. Dipólové elektromagnetické profilování v okolí př́kopu.

\section{Uncertainty in the subsurface trench outflow formation}

The experimental trench and the contributing sub-catchment area are located on the territory of the former clear-cut forest. During some rain events the preferential flow pathways behaving as local sources or drains were observed on the walls of the trench in years before the filling of the trench. Within the hillslope transect this phenomenon occurs where tree roots decayed and boulders or weathered bedrock particles are present. It may have significant impact on the development of the subsurface flow under specific condition. Due to the instability of the subsurface outflow formation the size of the sub-catchment contributing to the trench may slightly change in time. Uncertainties 
remain also with the respect to the shape and boundaries of the contributing sub-catchment due to unknown depth of the impermeable solid bedrock. For the trench vicinity, the solid bedrock depth was estimated by geophysical methods in 4-5 meter below the surface. It contains significant discontinuities which might be related to the geological fractures or varying degree of granite weathering and has to be considered a potential cause for the percolation of water underneath the trench. However, the saturated hydraulic conductivity of the soil layer as measured on undisturbed soil samples taken from the trench bottom at $70 \mathrm{~cm}$ below the surface, is lower than $10^{-7} \mathrm{~m} \mathrm{~s}^{-1}$. Compared to saturated hydraulic conductivity of higher layers (topsoil: $K_{s}=10^{-4} \mathrm{~m} \mathrm{~s}^{-1}$; horizons $20-60 \mathrm{~cm}$ : $\left.K_{s}=10^{-5} \mathrm{~m} \mathrm{~s}^{-1}\right)$, it may be assumed that the deeper strata of the weathered bedrock in 1 to 4-5 meter below the surface may contribute only partially to the rapid subsurface runoff and have little or no influence on the fast subsurface storm outflow. Although the collecting trench controls only a thin and shallow part of the soil profile, we assume that majority of rapid subsurface outflow is captured there.

\section{Results and discussion}

\section{Rainfall runoff events}

Results from the first vegetation season 1998 are presented in this contribution. In the period May to November 1998, four significant hydrological periods were recorded each of them consisting of one to three single rainfall events producing the outflow at the subsurface trench. Tab. 3 gives an overview of the subsurface runoff recorded in the trench collectors.

From Tab. 3 it is evident that major part of the trench outflow takes place at the bottom sections. As mentioned earlier at a depth of $60-70 \mathrm{~cm}$ the soil profile changes its structure towards the weathered bedrock material with a sharp decrease of saturated hydraulic conductivity. At the same depth the root pathway occurrence decreases. In consequence the vertical percolation attenuates and the lateral downslope flow component increases. A dominating portion of the outflow collected at the trench face has been found at its lowest collection horizons. The outflow increase effect due to the trench construction, which interrupts the subsurface flow lines and causes artificial drainage effect, should be counted for.
The rainfall runoff events selected for further analysis met the following criteria: each event was separated by at least 2 hours of the period without the precipitation and the total event rainfall was higher than $15 \mathrm{~mm}$. In many cases the selected events followed the longer periods of precipitation activity of the high total rainfall of low intensity. The selected events were classified according to statistics based on 24-hour rainfall totals for Uhliŕrská catchment over the period of 1981-1997 as shown in Tab. 4. The rainfall occurrence interval has only informative value since the analyzed 16year period of the observation is rather short.

Tab. 5 shows the results of the stormflow measurement in the subsurface trench (Fig. 2) for the selected rainfall events. The cumulative surface outflow in the Černá Nisa stream, measured at the Uhliŕrská gauging station, is the total cumulative outflow with subtraction of the baseflow of 0.048 $\mathrm{mm} \mathrm{h}^{-1}\left(25 \mathrm{l} \mathrm{s}^{-1}\right)$, typically observed prior to the event. The specific stormflow rate is $0.2-2 \mathrm{~mm} \mathrm{~h}^{-1}$ (approximately 100-1000 $\mathrm{s}^{-1}$ ), therefore the baseflow contribution has negligible effect on the total outflow amount.

The selected events can be divided into two sets according to the duration and the amount of outflow. One group represents summer storms of higher intensity and shorter duration of precipitation and outflow. Second group is formed by the autumn rainfall outflow events of longer duration and lower rainfall and outflow intensity. The fact worth of notice is that the total outflow caused by an intensive single rainfall event is very close to the precipitation total indicating minor storage effect within the catchment. Tab. 4 shows this comparison as an outflow ratio. However, during several longer periods of frequent precipitation, the total outflow amount compared to the rainfall event is even higher than the rainfall total. This results from the raised outflow above the baseflow by the antecedent event prior to the analyzed one.

To evaluate the outflow amount from the trench, two bottom horizons data are presented (Fig. 5). The rapid responsive nature of the outflow at the trench is caused by a small contributing area and a shallow depth of the soil profile. This space is further referred as a microcatchment. The thin, loosely structured organic soil with limited water storage capacity and high hydraulic conductivity results in a short travel time to reach the weathered bedrock zone, thus rapid response in the subsurface flow formation is observed. 
T a b l e 3. Distribution of the subsurface outflow from the collection trench (May-November 1998).

T a b u 1 k a 3. Rozdělení podpovrchového odtoku ze sběrného př́ḱkopu (květen-listopad 1998).

\begin{tabular}{cccccccc}
\hline & \multicolumn{3}{c}{ Subsurface outflow [litres] } & \multicolumn{3}{c}{ Percentage of subsurface outflow } \\
\hline Section & horiz. 1 & horiz. 2 & horiz. 3 & Total & horiz. 1 & horiz. 2 & horiz. 3 \\
A & 80 & 566 & 20811 & 21457 & $0.4 \%$ & $2.6 \%$ & $97.0 \%$ \\
B & 85 & 9 & 30855 & 30949 & $0.3 \%$ & $0.0 \%$ & $99.7 \%$ \\
\hline
\end{tabular}

T a b l e 4. Rainfall event characteristics at Uhlírská catchment.

T a b u 1 k a 4. Charakteristiky srážkových událostí v povodí Uhliřská; 1 - datum epizody, 2 - trvání deště, 3 - srážkový úhrn, 4 průměrná intenzita deště, 5 - doba opakování deště, 6 - celková předchozí srážka, 7 - období bez srážek před epizodou.

\begin{tabular}{|c|c|c|c|c|c|c|}
\hline Day of the event ${ }^{1)}$ & $\begin{array}{c}\text { Rainfall } \\
\text { duration }^{2)} \\
{[\mathrm{h}]}\end{array}$ & $\begin{array}{c}\text { Rainfall } \\
\text { total }^{3)} \\
{[\mathrm{mm}]}\end{array}$ & $\begin{array}{c}\text { Average } \\
\text { rainfall inten- } \\
\text { sity }^{4)}\left[\mathrm{mm} \mathrm{h}^{-1}\right]\end{array}$ & $\begin{array}{c}\text { Rainfall occur- } \\
\text { rence interval } \\
\text { [days] }\end{array}$ & $\begin{array}{c}\text { Total antecedent } \\
\text { precipitation }{ }^{6} \\
{[\mathrm{~mm}]}\end{array}$ & $\begin{array}{l}\text { Period of ante- } \\
\text { cedent precipita- } \\
\text { tion }^{7}[\text { days }]\end{array}$ \\
\hline 13.6 .1998 & 18 & 66.6 & 3.7 & 769 & 44.4 & 6 \\
\hline 6.-8. 7. 1998 & 51 & 44.1 & 0.9 & 250 & 10.2 & 5 \\
\hline 10. 7.1998 & 18 & 23.3 & 1.3 & 60 & 69.4 & 9 \\
\hline 13. -15.9 .1998 & 39 & 44.4 & 1.1 & 251 & 41.3 & 8 \\
\hline 16.9. 1998 & 7 & 20.2 & 2.9 & 39 & 94.4 & 12 \\
\hline 18. 9.1998 & 19 & 16.4 & 0.9 & 23 & 122.1 & 13 \\
\hline 1. 11.1998 & 10 & 35.0 & 3.5 & 151 & 64.5 & 7 \\
\hline
\end{tabular}

T a b 1 e 5. Outflow event summary.

T a b u 1 k a 5. Přehled odtokových událostí; 1 - období epizody, 2 - srážkový úhrn na Uhlířské, 3 - trvání odtokové události, 4 kumulativní odtok, Černá Nisa, 5 - odtoková výška epizody, 6 - odtokový součinitel, 7 - kumulativní odtok v půdním horizontu A3, 8 - kumulativní odtok v půdním horizontu B3, 9 - mikropovodí k A3, 10 - mikropovodí k B3.

\begin{tabular}{|c|c|c|c|c|c|c|c|c|c|}
\hline $\begin{array}{l}\text { Period of the } \\
\text { event }\end{array}$ & $\begin{array}{c}\text { Rainfall } \\
\text { total at } \\
\text { Uhlírská }^{2)} \\
{[\mathrm{mm}]}\end{array}$ & $\begin{array}{c}\text { Period of } \\
\text { outflow } \\
\text { event } \\
\text { [hours] }\end{array}$ & $\begin{array}{c}\text { Cum. } \\
\text { outflow, } \\
\text { Černá } \\
\text { Nisa }^{4)} \\
{\left[\mathrm{mil.} \mathrm{m}^{3}\right]}\end{array}$ & $\begin{array}{c}\text { Outflow } \\
\text { height of } \\
\text { the event }{ }^{5)} \\
{[\mathrm{mm}]}\end{array}$ & $\begin{array}{l}\text { Outflow } \\
\text { ratio }^{6)}\end{array}$ & $\begin{array}{c}\text { Cum. } \\
\text { outflow at } \\
\text { soil hori- } \\
\text { zon } \mathrm{A3}^{7)} \\
{\left[\mathrm{m}^{3}\right]}\end{array}$ & $\begin{array}{c}\text { Cum. } \\
\text { outflow at } \\
\text { soil hori- } \\
\text { zon B3 } \\
\left.{ }^{8} \mathrm{~m}^{3}\right]\end{array}$ & $\begin{array}{c}\text { Micro- } \\
\text { catchment } \\
\text { area of } \\
\mathrm{A3}^{9)}\left[\mathrm{m}^{2}\right]\end{array}$ & $\begin{array}{c}\text { Micro- } \\
\text { catchment } \\
\text { area of } \\
\mathrm{B}^{10)}\left[\mathrm{m}^{2}\right]\end{array}$ \\
\hline 13.6 .1998 & 66.6 & 52 & 0.105 & 56.34 & 0.85 & 2.44 & 4.41 & 36.69 & 66.30 \\
\hline 6. 7. 1998 & 44.1 & 90 & 0.076 & 40.53 & 0.92 & 0.97 & 1.33 & 22.07 & 30.10 \\
\hline 10. 7.1998 & 23.3 & 52 & 0.055 & 29.25 & 1.26 & 1.57 & 2.70 & 67.30 & 115.99 \\
\hline 15.-18.9. 1998 & 56.9 & 96 & 0.164 & 87.47 & 1.54 & 6.44 & 7.57 & 113.20 & 133.07 \\
\hline 1. 11. 1998 & 35.0 & 58 & 0.092 & 49.05 & 1.40 & 2.55 & 3.76 & 72.80 & 107.54 \\
\hline
\end{tabular}

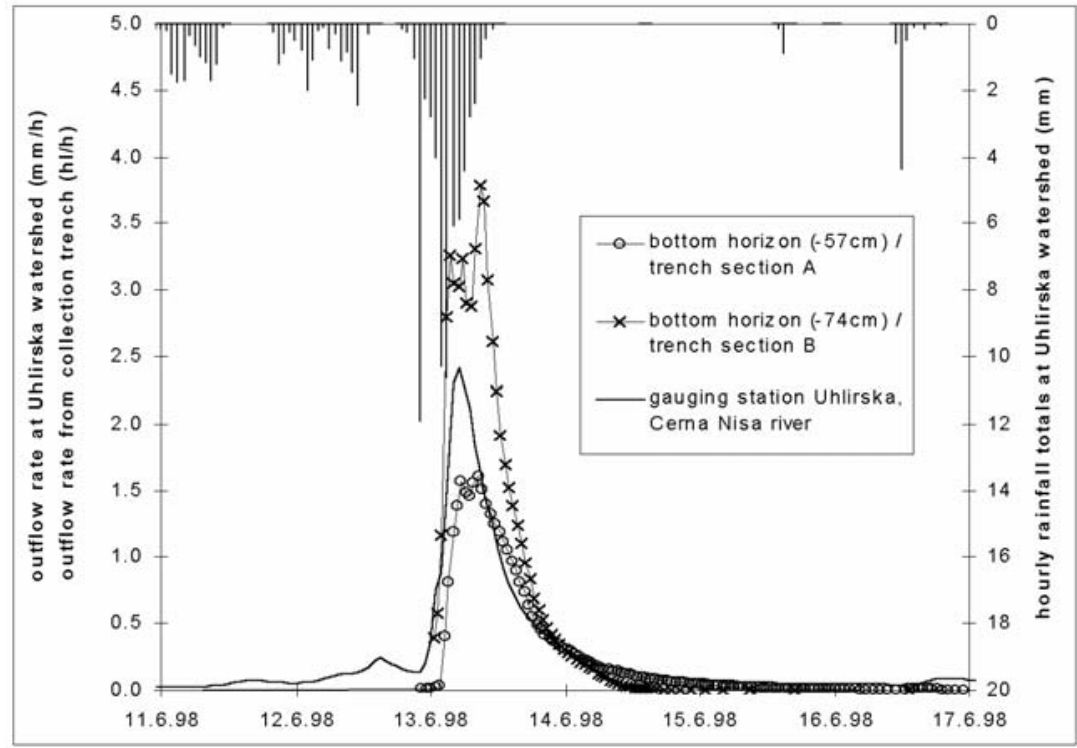

Fig. 5. Outflow episode - June 1998.

Obr. 5. Odtoková epizoda - červen 1998. 
The mean corresponding microcatchment areas (Tab. 5) for the subsurface outflow events were derived for each episode as a ratio of the total outflow at the trench bottom horizons A3 and B3 and the total rainfall depth. The microcatchment areas are not constant, but vary according to the total rainfall amount, the total antecedent soil moisture content conditions and the duration of the rainfall event. The outflow amounts from each trench section vary significantly among each other. This might be due to the extreme heterogeneity of the soil profile.

The dynamics of the outflow from the trench section $\mathrm{A}$ is more adequate for the soil profile with a small amount of visible preferential pathways. In the section $\mathrm{B}$, the distinct flow pipes, approximately $1 \mathrm{~cm}$ wide, were found at the trench face during and after the heavy rainfall. The ratio of the total outflow comparing sections $\mathrm{A}$ to $\mathrm{B}$ of the trench changes from 1.83 for a heavy rainfall event to 1.17 for a sequence of short events. This difference may originate from the different wetting patterns: gradual - caused by a low intensity, longer duration rain and sudden - by high intensity and short duration storm. In the gradual wetting scheme, water is delivered into smaller pores as well; in storm event, water infiltrates into the drier soil profile via larger macropores and pipes, which become the main contributor of the subsurface flow. The mean outflow rate expressed as the amount of the outflow at the trench face area has an order of $10^{-4} \mathrm{~m} \mathrm{~s}^{-1}$. Al- though this value is relatively high, the actual velocities in the flow pathways could be even one to two orders higher because the soil profile is drained in distinct spots, representing only the negligible fraction of the total seepage area.

Fig. 5 and Fig. 6 present the dynamics of the trench outflow compared with the catchment streamflow. It is clearly evident that the flow hydrographs have very similar shapes. Rising limbs are very steep and recession limbs last for a short time as well, supporting the hypothesis that subsurface flow from the shallow soil horizons of the slopes in the catchment is the main forming part of the outflow from the whole catchment.

\section{Relationship between the soil moisture content and the outflow}

The soil moisture content of the soil profile was determined indirectly (Šanda, 1999). The retention curves based on the soil samples collected in the vicinity of the trench were fitted by the van Genuchten formula (van Genuchten, 1980) and are used as a soil water suction - soil moisture content transfer function. From the point measurement at each tensiometer triplet, the soil water column equivalent is obtained as the sum of soil moisture content representing each horizon, measured by the tensiometers, and multiplied by the depth of corresponding soil layer.

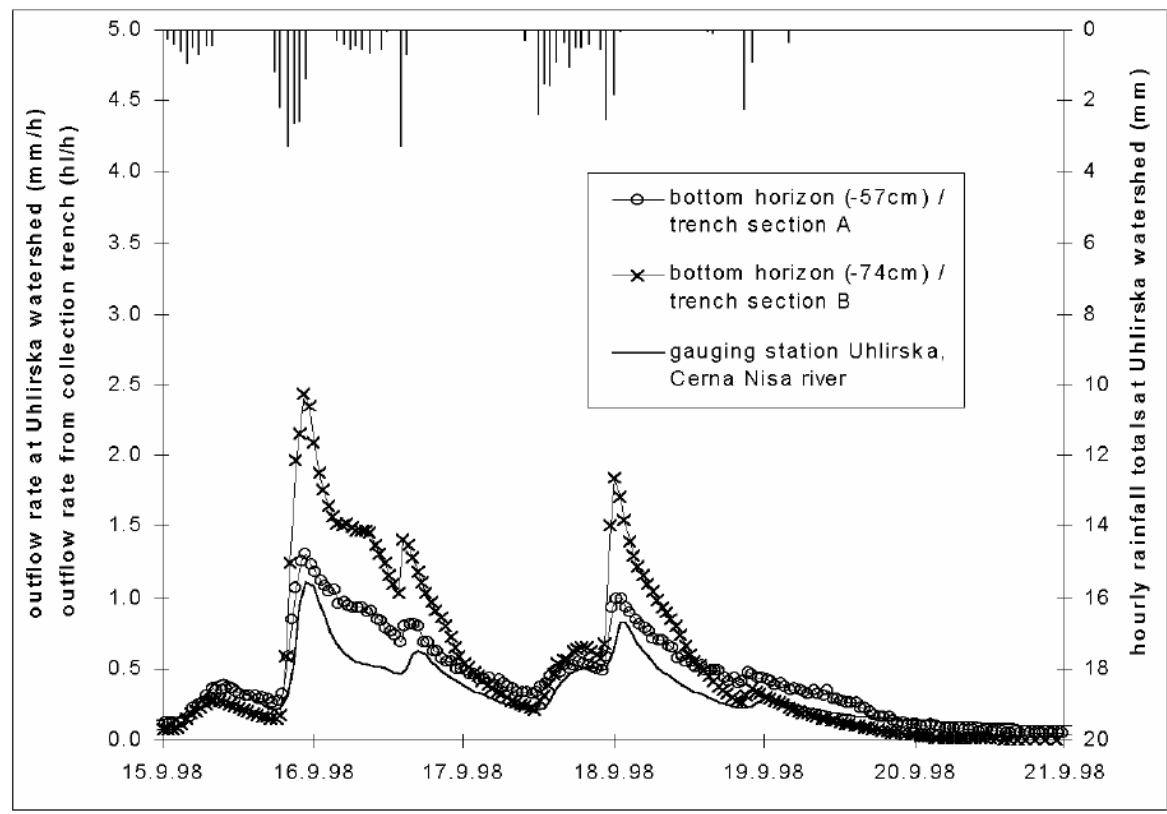

Fig. 6. Outflow episode - September 1998.

Obr. 6. Odtoková epizoda - září 1998. 


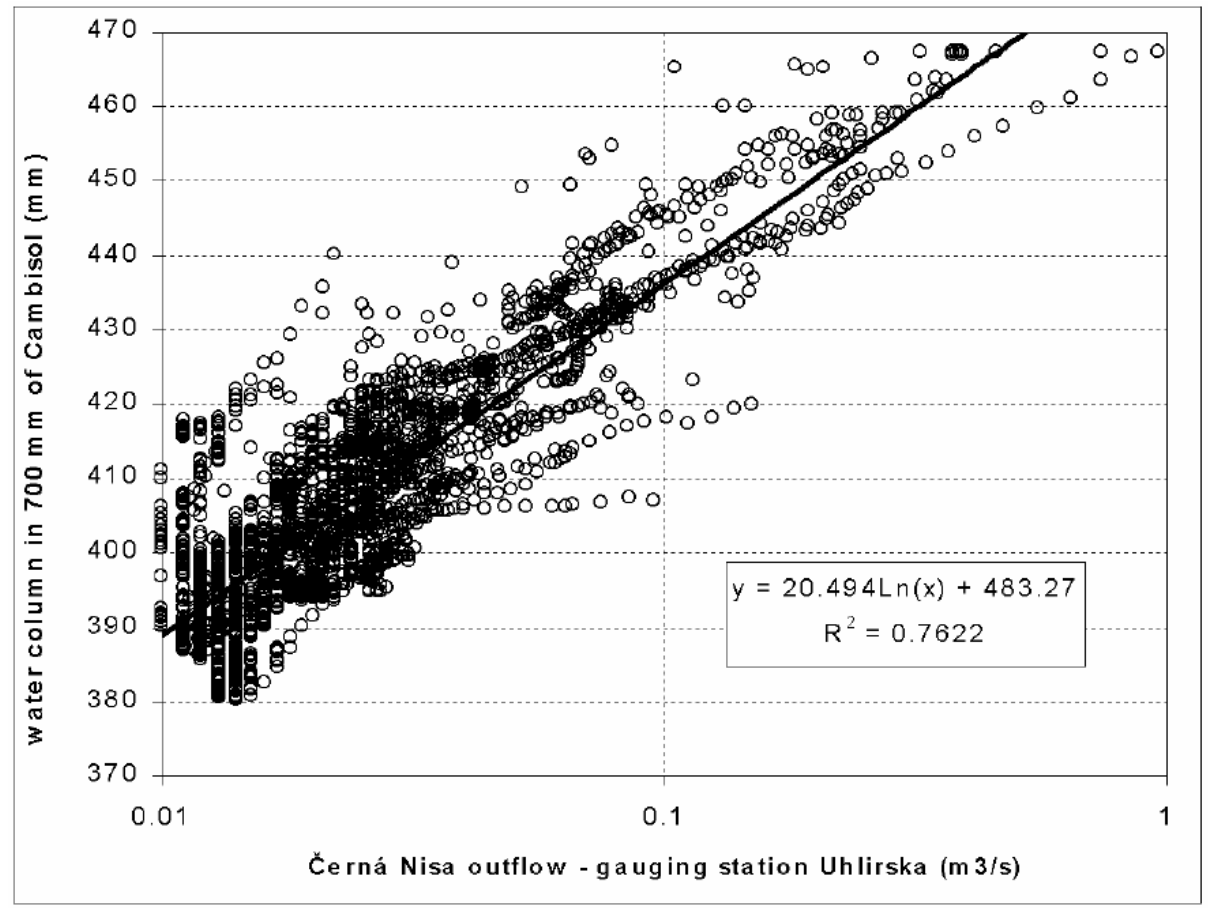

Fig. 7. Relationship between the soil water content and the outflow from the catchment. Obr. 7. Vztah obsahu vody v půdě a odtoku z povodí.

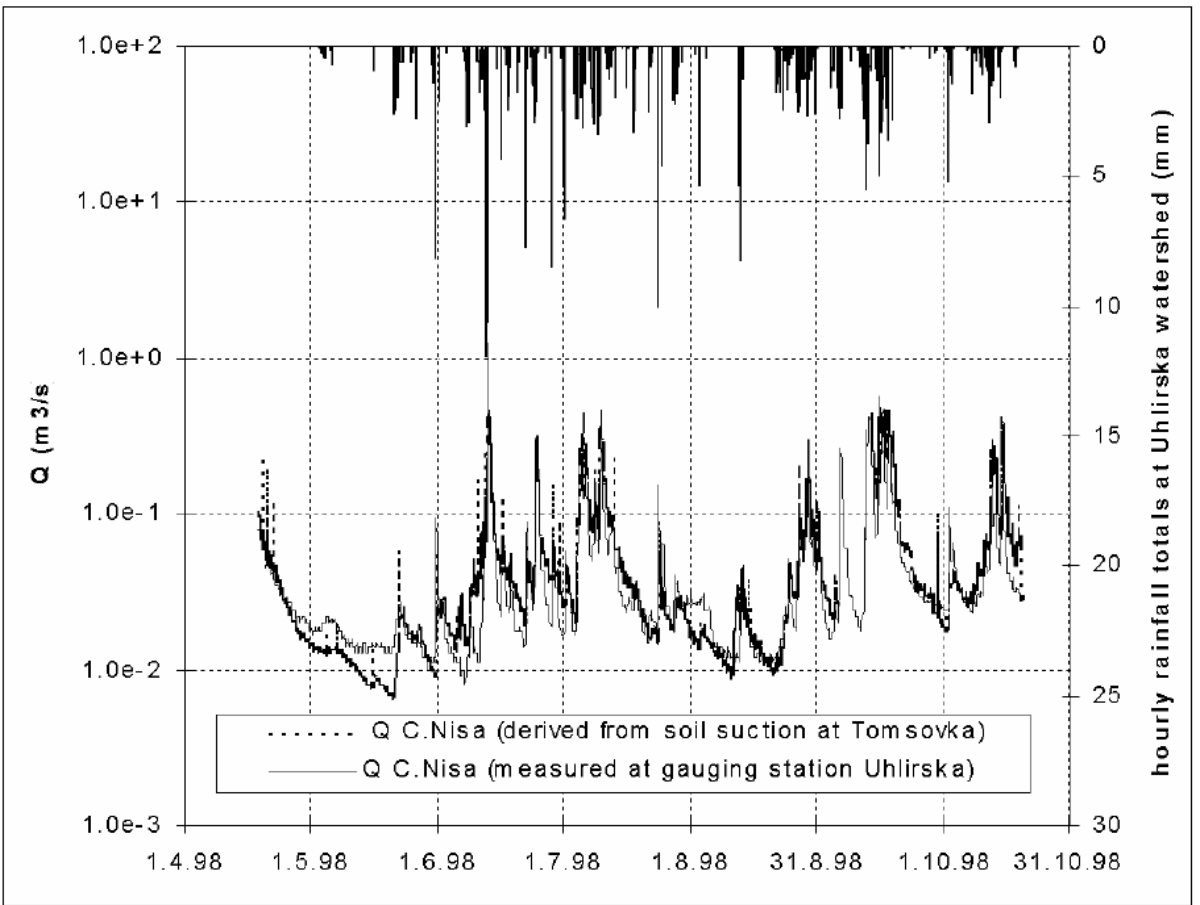

Fig. 8. The outflow from the catchment as derived on the basis of the soil suction measurements. Obr. 8. Odtok z povodí získaný na základě měření půdního sacího tlaku.

Fig. 7 shows the relationship of the soil moisture content and the outflow from the catchment. The upper $70 \mathrm{~cm}$ of the soil profile, where soil water suction readings are carried out, was compared with the instant catchment streamflow. Corresponding values are well correlated by a logarithmic formula with the correlation coefficient of 0.76 , which indicates a relatively strong relationship for the natural 
conditions. The water regime of the subsurface, here represented by the soil moisture content, essentially affects the subsurface runoff formation that controls the channel surface flow. Fig. 8 shows the course of the outflow rates derived upon the optimised relationship of the soil moisture content and streamflow presented over the whole vegetation season.

\section{Relationship between the hydraulic head and the outflow}

Measurement of the soil suction by means of tensiometers can indirectly detect the changes of the soil moisture content with one order higher precision than direct soil moisture content measurement here performed by the neutron probe. Due to the studied soil type, only small changes in soil moisture content may cause remarkable difference in the shift of the soil water suction. The soil water suction measurement allows the normalization and transferability of the derived conclusions to other catchments better than absolute soil moisture content data. Due to the differences in the soil types and their water retention characteristics, driving forces influencing the runoff formation cannot be easily evaluated.

The changes of the subsurface outflow in the course of the rainfall were compared with the water table relative to the bottom of the section of the sampling trench. The readings of the soil water suction, transformed to the water table values were performed by the tensiometers installed into the deepest horizon referring to the deepest horizons of $\mathrm{A}$ and $\mathrm{B}$ trench sections. Three major runoff events are presented in Fig. 9 and Fig. 10. These figures show the exponential increase of the runoff with the linear increase of the water table, which can be simplified by the logarithmic function with relatively high degree of correlation. However, each of the sampled trench horizons exhibits quite different pattern for the transfer function. In the section A3, the flow does not increase so rapidly with the increase of the water table as in section B3. This may be due to the smaller number of visible preferential pathways observed mostly in B3 horizon. When a certain water table threshold is reached, the outflow grows rapidly only with a minor additional groundwater table rise.

In Fig. 9 and Fig. 10, the flow hysteresis is evident. Rising and falling limb of the outflow hydrograph does not relate to the same water level when adequate flow is reached or vice versa. Several minor hysteresis loops can be observed when a series of partial rising and falling limbs of the hydrograph are plotted.

Results shown in the Fig. 9 and Fig. 10 prove that the appearance of the perched water table in the shallow soil profile with preferential pathways is closely related to the flood subsurface runoff and contributes directly to the flood formation. In the headwater mountainous catchments, flash floods can be related to these soil variables, which can be easily monitored and serve for a flood warning after certain time of observations and consequent calibration.

\section{Practical experience with data sensing devices in the longer period of time}

During 7 vegetation and 5 non-vegetation periods (1998-2003) of the hydrological regime monitoring at the hillslope, extended knowledge of the data sensing in field has been collected. All of the automatic equipment has been controlled by two data loggers: Campbell Scientific CR10X-1M with AM416 multiplexor, controlling pressure transducers, thermometers and a part of flow tipping buckets and Newlog 3 logger, as the supplemental device, served for the record of the rest of the equipment producing pulse signals. Both the loggers proved the reliability in the harsh environment, although the temporal malfunction occurred several times. The larger capacity of the flash memory, which is the state-of-the-art solution, assured the security to prevent the data loss in such situation.

Two types of the tensiometers have been used for the soil water suction measurement: acrylic tensiometer (Soilmoisture Inc, Goleta, CA, USA) and grey PVC tensiometer (Soil Measurement Systems, Tuscon, AZ, USA) both equipped with 1/4" NPT thread. Within the years, Soilmoisture tensiometers proved to be better choice for the digital sensing, due to the durability of the acrylic body with no joints. On contrary to, SMS tensiometer in the design with threaded joint and rubber stopper has the advantage of simultaneous automated data collection and manual calibration, using precise Tensime$\operatorname{ter}^{\mathrm{TM}}$ unit for the pressure reading via septum stopper. Overwhelmingly, thermal fluctuations in the field, namely the frost decreased the lifetime of any of these tensiometers tremendously.

For the pressure measurements itself, two of the pressure sensors have been used: Soilmoisture 5301 current transmitter and Honeywell 236PC15GW pressure transducer, both in $1 / 4$ NPT thread design. 


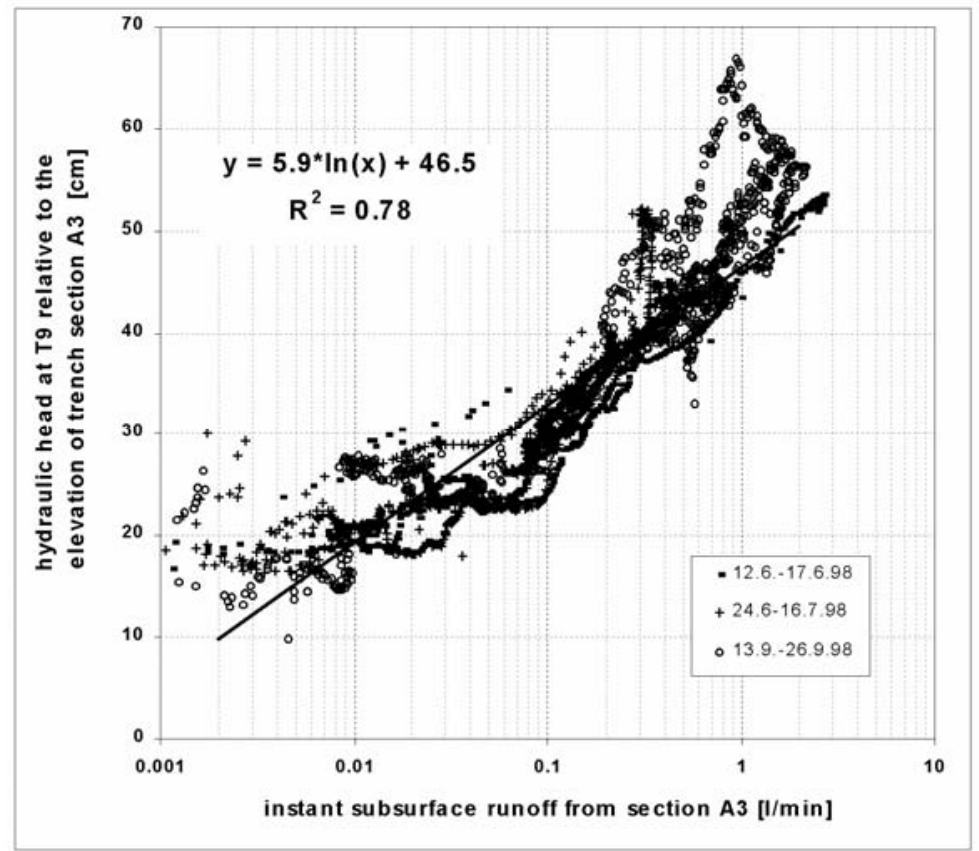

Fig. 9. Relation of hydraulic head in soil profile and subsurface runoff at trench section A.

Obr. 9. Vztah hydraulické výšky v půdním profilu a podporchového odtoku z prríkopu, sekce A.

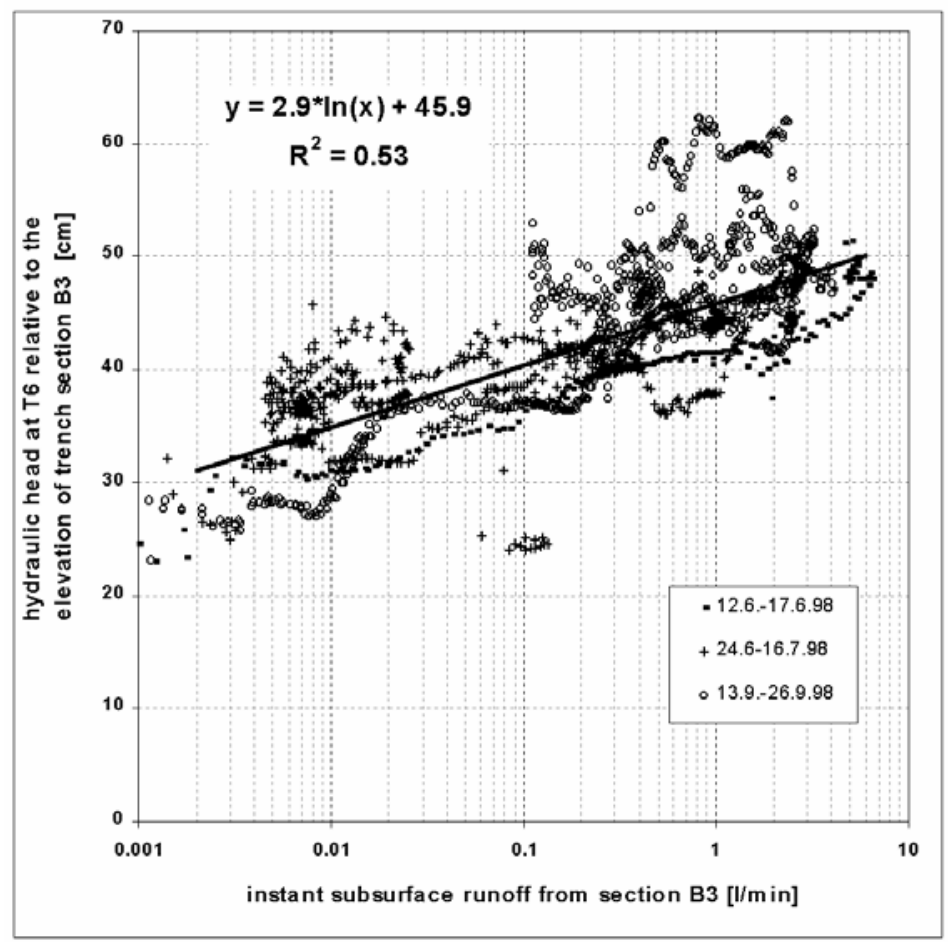

Fig. 10. Relation of hydraulic head in soil profile and subsurface runoff at trench section B.

Obr. 10. Vztah hydraulické výšky v půdním profilu a podporchového odtoku z př́íkopu, sekce B.

Soilmoisture transmitter fits to the same brand tensiometer and seals it snugly with an $\mathrm{O}$ ring. Honeywell sensor fits this tensiometer as well, however sealing requires an advanced method.
Both of the sensors fit the SMS tensimeter well using the teflon tape. The assurance of a good airtight joint on the tensiometer-transducer interface is of a major importance for the environment where 
the frequent servicing cannot be achieved. Due to its nature, Soilmosture 5301 as a current transmitter occupies less channels on the logger than Honeywell differential voltage transducer. On contrary to, its power consumption is higher and its use in the freezing conditions is impossible. The Honeywell sensors can operate in frost, however their overall lifetime is shorter, decreased in the low temperature or the higher suction imposed during drier conditions.

Regarding the collection of the outflow, the 200 $\mathrm{ml}$ to $1000 \mathrm{ml}$ volume tipping buckets made of plexiglass or PVC plastic were used. Plexiglass showed non-applicability in the harsh field environment due to its fragility to shock and frost. The flexible $2 \mathrm{~mm}$ thick orange or grey PVC proved the overall good durability. For the heavy duty flow tipping buckets, $3 \mathrm{~mm}$ grey PVC plastic sheets have been used. The standard PVC glue for joints did not prove to fit the desired needs, therefore plastic welding of joints with combination of epoxy resin is acceptable choice to overstrain in the freezing water or swelling ice. The plastic body also insures no electrical contact with the ground, therefore no metal parts near the sensing unit were used. The sturdy $100 \mathrm{mOhm}$ light duty reed switch with an actuator magnet was used for the pulse generation. It proves durability for a heavy and moving equipment under permanent mechanical shock, however can cause signal errors due to the magnetic induction when the frequency is high. Small, glass coated mechanical switches with the magnet, commonly used in raingauge design seem to be an adequate alternative, when installation assures the protection of such fragile part.

\section{Conclusions}

The collected data show a quick response of soil water suction decrease according to the rainfall. Almost simultaneous reaction in all soil horizons implies a rapid vertical flow. The unsaturated regime within the soil profile prevails nevertheless the soil moisture content was close to the saturation. No permanent water table has been observed on the slope. Only a narrow range of soil moisture variation was observed, and thus the step change between the saturated and unsaturated flow regime and vice versa is very fast and sudden. The heterogeneity of the subsurface flow is documented by comparison of such values at two trench sections and their three soil horizons. Local preferential flow paths are conducting water at significantly variable rates.

The results of the measurement lead to the following conclusions about the nature of the storm flow generation in the catchment under this study: A significant fraction of the rain falling on the hillslope infiltrates vertically towards the nearly impermeable weathered bedrock via preferential pathways, the remaining part slowly infiltrates into the soil matrix. A saturated layer is built up in the soil profile above the weathered granite layer and a rapid subsurface flow is formed there. There are significant relationships between groundwater table, soil moisture content, subsurface runoff, soil water suction and the total outflow from the catchment, showing that the transformation of rainfall into runoff in the area where soils are shallow, is controlled by the soil moisture content or the soil suction in the subsurface. Storm flow is dominantly conducted by preferential pathways in the subsurface when saturation is reached.

Acknowledgements. This research has been supported by the project 205/06/0375 of the Grant Agency of the Czech Republic and by the project $\mathrm{VaV} \mathrm{SP/2E7/229/07} \mathrm{of} \mathrm{the} \mathrm{Ministry} \mathrm{of} \mathrm{Environ-}$ ment of the Czech Republic.

Authors also gratefully thank number of $\mathrm{PhD}$ students of the Czech Technical University in Prague and the staff of the Water Research Institute, T.G.M., public research organisation, Prague for their enduring effort and willingness to help which made this field research pursuable.

\section{REFERENCES}

BAČA P., BAČOVÁ MITKOVÁ V. 2007: Analysis of seasonal extreme flows using peaks over threshold method. J. Hydrol. Hydromech., 55, 1, 16-22.

KIRCHNER J.W., 2003: A double paradox in catchment hydrology and geochemistry. Hydrol. Process., 17, 871-874.

SNĚHOTA M., SOBOTKOVÁ M., CÍSLEROVÁ M. 2008: Impact of the entrapped air on water flow and solute transport in heterogeneous soil: experimental set-up. J. Hydrol. Hydromech., 56, 4, 247-256.

ŠANDA M., 1999: Runoff Formation in the Hillslope Subsurface. [Dissertation thesis.] (In Czech.) CTU in Prague.

ŠANDA M., VOGEL T., CÍSLEROVÁ M., 2005: Hydrograph Formation in a Hillslope Transect. Progress in Surface and subsurface Water Studies at Plot and Small Basin Scale. Proceedings of 10th ERB Conference. Turin, Italy, 13-17 October 2004., pp. 21-26. UNESCO IHP-VI, Technical documents in Hydrology, No. 77.

TACHECÍ P., ŠANDA M. 2000: Ponded infiltration experiments at Uhlírská catchment. Catchment hydrological and biochemical processes in changing environment. Proceedings of the Liblice Conference (22-24 September 1998). Edited by V. Elias and I.G. Littlewood, IHP - V, Technical 
Documents in Hydrology, No. 37, UNESCO, Paris, 2000, SC-2000/WS/38, p. 273-279.

VAN GENUCHTEN, M.Th. 1980: A closed Form Equation for Predicting the Hydraulic Conductivity of Unsaturated Soils. Soil Science Society of America Journal, 44, 892-898 .

Received 19 February 2009

Scientific paper accepted 14 October 2009

\section{TRANSFORMACE HYDROGRAMU PODPOVRCHOVÉHO ODTOKU NA SVAHU}

\section{Martin Šanda, Milena Císlerová}

V oblasti s dominantním podpovrchovým odtokem v povodí Uhlířská v Jizerských horách byl uskutečněn kontinuální hydrologický a klimatický monitoring $\mathrm{s}$ cílem popsat a vyhodnotit transformaci srážky na odtok. Půdní profil tvoří dystrická kambizem na zvětralém žulovém podloží. Půdní pokryv je mělký a horizonty jsou velmi heterogenní. Na vybraném svahu je sledován podpovrchový odtok a půdní sací tlak ve třech půdních horizontech sběrného podpovrchového př́ḱkopu. Soubor změřených dat poukazuje na rychlou odezvu půdního sacího tlaku v jeho poklesu v závislosti na srážce. Téměř simultánní reakce všech půdních horizontů indikuje rychlé vertikální proudění. V půdním profilu převládá nenasycený stav, přestože je půdní vlhkost blízko nasycení. Během výzkumu nebyla na svahu pozorována stálá hladina podzemní vody. Z pozorování vyplývá úzký pás hodnot půdní vlhkosti, kdy změna $\mathrm{z}$ nenasyceného do nasyceného stavu a nazpět je velmi rychlá a náhlá. Heterogenita proudění pod povrchem je dokumentována porovnáním odtoku dvou sekcí sběrného př́kopu v jeho třech půdních horizontech. Lokální preferenční cesty provádějí vodu ve významně proměnlivých intenzitách.

$\mathrm{Na}$ základě této studie výsledky měření vedou $\mathrm{k}$ následujícím závěrům ohledně povahy tvorby rychlého odtoku v povodí: Významný podíl srážek dopadajících na svahy infiltruje vertikálně směrem k velmi málo propustné vrstvě zvětralinového pláště nad podložím preferenčními cestami. Zbývající část infiltruje pomalu do půdní matrice. Na hranici zvětralé žuly se vytváří nasycená vrstva, kde je formováno rychlé podpovrchové proudění směrem po svahu. Vztahy mezi hladinou podzemní vody, objemovou vlhkostí půdy, podpovrchovým odtokem, půdním sacím tlakem a celkovým odtokem z povodí jsou těsné. Tyto závislosti ukazují, že transformace srážky na odtok v oblasti, kde je půdní profil mělký, je určována vlhkostí půdy, ev. vyjádřené formou půdního sacího tlaku. Pokud dojde k nasycení, je rychlý povodňový odtok veden převážně preferenčními cestami pod povrchem. Přes tato zjištění není mechanismus tvorby odtoku zatím jednoznačně popsatelný.

Seznam symboli̊

$K_{s}$ - nasycená hydraulická vodivost $\left[\mathrm{m} \mathrm{s}^{-1}\right]$. 